\title{
Subsidiarity and Federalism: An Old Concept with Contemporary Relevance for Political Society Mark Friesen
}

\section{Introduction}

Historically human societies have never collectively organized, politically or socially, in any singular, standardized and/or universal way. Beginning with the Peace of Westphalia in 1647 the nation-state gradually proliferated as a legitimate manifestation of collective human organization at a global level. This proliferation has culminated in the standardization of a singular means of mobilizing and organizing human societies. The statist age that began in the $16^{\text {th }}$ and $17^{\text {th }}$ centuries consolidated and centralized the political power of the state. Divergent factions and regional power blocks within European states were discouraged, as politics became centralized at the national level. The proliferation of the nation-state represented the standardization of human political organization according to a single model. Given that there are, and have been, a variety of means by which humans identify and organize politically, this suggests that this universal acceptance and entrenchment of one model may be somewhat inappropriate.

However, federal political systems offer the opportunity to accommodate these divergent political realities. In a federal political system governance and authority are held and exercised at different levels of government - some powers are held by the central, national, government and some powers are held by the social and/or political units that are constituent parts of the whole nation. In so far as the world is organized into nations with a central, unitary, level of government which represents aggregate wholes of vast multitudes of communities it is doubtful that the nation-state model would have the capacity to accommodate for differences in cultures and political realities within 
their borders. However, federalism, and the principle of subsidiarity, offer the means to accommodate widely divergent political realities within nations. In this paper I intend to explore federalism and the principle of subsidiarity. I understand the nation-state from two general perspectives: (1) as a standard unit of human organization which receives universal assent and; (2) as an entity which is intended to be an aggregate whole comprised of sub-national parts.

This paper will demonstrate that the nation-state is in fact a legitimate aggregate of human political society so long as it retains some degree of dependence on the parts of which it is constituted. This is what is implied by subsidiarity, as I intend to demonstrate. The first section will examine the historical roots of this principle, and some of its theoretical foundations. The second section will briefly outline the historical circumstances and theoretical foundations which underlie the development and understanding of the nation-state today. In the last section, the paper will examine the principle of subsidiarity in federal systems and federalist ideas in Europe, with a particular focus on the European Union (EU). The application of this principle in the integration of Europe, as demonstrated by the EU, offers an example of how this principle can be applied in practice. I intend to suggest that this principle is significantly relevant for federal states, and not just supra-national unions.

The principle of subsidiarity maintains that issue areas and political authority are only exercised at the national state level if it is deemed necessary by the constituent units, and if the issue or political authority would better be dealt with at the national level. Otherwise, political authority should remain in the hands of the units which actually constitute society, or at more localized levels of political society. It is only through 
recognition and respect for this principle that nation-states can be legitimate aggregates of human political society. Subsidiarity implies that political authority ultimately rests with the constituent units of society, and is only transferred to a federal/national level if it is absolutely necessary. The existence of the national level of society and government ultimately depend upon authority which is delegated from the constituent units. Federalism, which is based on the notion of subsidiarity, has the capacity to accommodate the differences in human social and political realities, and the divergent ways through which humans organize themselves. The European Union is a prime example of this, and it clearly illustrates the considerable relevance of this principle for political society today.

\section{The Political Theory behind Subsidiarity and Federalism}

A federation can be loosely described as a political system that has both some degree of shared rule through common institutions while simultaneously providing for some degree of autonomous rule of the constituent units. ${ }^{1}$ Thus, there is an attempt to provide for both unity and diversity within a state or nation. Federal systems, however, can take a variety of different forms including "quasi-federations", "federations", and "confederacies". ${ }^{2}$ Most federal states provide for some regional autonomy for territorially delineated units. The nature of these units varies among federal states. There can be ethnic, linguistic, and cultural differences between the regions or federal units. The important point to note, however, is that there has been a perceived need to retain some autonomy and powers of authority for the regions and/or units that comprise a federal state. Carl Schmitt offers an excellent description of the distinction between a unitary state and a federal one. According to Carl Schmitt, control of the territory by the 
state may occur in two ways: either with a territorial articulation of power among the parts on the dependent whole - the centre - which monopolizes control; or with one where everything, including the centre, depends on the parts, and central control is distributed between the whole and the parts. The first is a unitary state, while the second is a federal one. ${ }^{3}$

Some of the issues that have to be considered in the formation of a federal state include the jurisdictions to be accorded to each level of government, where legislative and executive powers will lie, and, one of the most important considerations for the purposes of this paper, whether powers are devolved from the central government or whether the powers of the constituent units are constitutionally entrenched and exist at the regional level independently of devolution from the federal central government. This paper is not oriented towards the specifics of exactly how powers are split between the federal/national order of government and the regional levels, however, this last notion of whether the powers that exist at the regional level are dependent upon devolution from the national government, or whether the regional units have entrenched authority is an important consideration. Federalism divides the sovereignty of the state between a central government and regional governments ${ }^{4}$, and often times even a third order such as at local or municipal levels of government. In most federal systems some sovereignty exists at the regional/unit level. However, it is possible that this sovereignty only exists through devolution from the central government. If this is the case, the implication is that it is the central/national level of government that has the most political legitimacy and a legitimate mandate to exercise authority. If regional autonomy and sovereignty exist independently of recognition and affirmation from the central government, then it is 
implied that these levels of government and society have some degree of legitimacy and authenticity as a level of governance and for the exercise of political authority in themselves.

At the outset, this paper established two perspectives from which the nation-state can be understood or conceived. The fundamental characteristics of the nation-state are standard and universally recognized in government institutions throughout the world. In addition, the nation-state is an aggregate whole, comprising the sum of a multitude of societies. Is the nation-state always a legitimate aggregate whole - an authentic entity representative of its sub-national parts? In theory, the aggregate whole exists as a manifestation of its constituent parts. Its existence should depend on continual affirmation and recognition from the parts. If it is not - then what is it? Federal systems are typically established because of a perceived need to share governance and institutions to some degree. No state would likely exist if there were no perceived need for unity. In what follows I intend to argue that the functional need of nation-states should continually be emphasized, in that their existence should depend on the continual perception that some unity is necessary. This achieves authenticity and legitimacy for the federal/national order of government and political society - in that some sort of real unity exists or is necessary. This is best realized through the practice of subsidiarity.

The notion of subsidiarity originated in ancient times and was first applied within the Roman Catholic Church. ${ }^{5}$ The idea of federalism was first developed in the context of 16th century theology during the Reformation and became an integral part of political thought. ${ }^{6}$ The principle of subsidiarity has to do with conditions of subsistence and support. It is derived from the Latin root subsiduum, which refers to assistance in terms 
of the smaller matters of life. ${ }^{7}$ Initially, subsidiarity was perceived as an integral part of federalism, when federalist ideas were just starting to emerge. This was a sort of response to the sort of totalitarian experience that was about to begin in Europe, whereby rulers would be able to consolidate power and control over vast lands and large numbers of peoples.

It is at this point that the work of Johannes Althusius gained significance. He was a writer and a philosopher who is perceived by some as the first federal theorist or the first "federalist". In 1603 he published the work Politica Methodice Digesta in which he set forth his ideas concerning federalism and the nature of society. For him, society and the state were formed through a series of successive pacts which pushed them into associations. These associations took the form of either 'social pacts' or 'pacts of subjugation'. 'Social pacts' are pacts that guarantee respect for the autonomy of different communities and 'pacts of subjugation' are pacts that attempt to organize these communities hierarchically. ${ }^{9}$ It is a matter of priority that the pacts of subjugation not achieve a level of superiority over the other pacts of society, and as Althusius wrote:

...interference (between pacts) is circumscribed by law, because it must remain partial. Each part forms with others a larger part through contract that is discussed rigidly and assorted legally, simultaneously protecting its domain of strict economy. It participates actively in the new power created above it. It watches it attentively. If necessary, it deposes it. It ensues from the very existence of the parts. ${ }^{10}$

The last line in particular has substantial relevance. The aggregate whole - the sum of the pacts which comprise society - 'ensues from the very existence of its parts'. It never achieves a level superior to the smaller units. Althusius maintained that freedom does not emanate from the sovereignty of the larger whole, but from the autonomy of the smaller parts. Pope Pius XI encapsulates well the vision of society held by Althusius and the more precise meaning of subsidiarity: "What the individual is able to create through his 
own initiative and with his own energies should not be taken from him and attributed to social activity, so it is unjust to appropriate for the greater and super ordinate community what the smaller and subordinate community creates and contributes to the betterment of the earth." ${ }^{11}$ Whatever super ordinate authority exists should not appropriate the functions of the smaller units of society.

Today, the significance and relevance of this term for society in general often seems to be somewhat diminished. Ferran Requejo describes subsidiarity as a principle according to which a political decision, or at least its implementation, must be carried out at the closest possible level to the people. ${ }^{12}$ As I will demonstrate shortly, this is as far as any conception of subsidiarity goes today. Perceptions and use of this term conceive of subsidiarity as little more than a principle advocating levels of governance at the smallest levels of society possible - as close to the people as possible. However, as the quotes above suggest, the term implies much more than that. Subsidiarity does not just imply governance at the smallest level possible.

Any society is composed of smaller constituent parts. Nation-states, by their very nature, also have to be composed of smaller constituent parts. Ferran Requejo states further that the basic aim of plural federalism is that of regulating different types of agreements in accordance with both the functional sphere that is to be regulated and the characteristics of the federated units. ${ }^{13}$ If this is the case then it is crucial that a principle whereby the characteristics of the federal units are continually emphasized and recognized be upheld. Subsidiarity is just such a principle. Subsidiarity implies that the federal/national order of government wields and exercises authority in a manner that is reflective of the characteristics of the federal and constituent units. Thomas Hueglin 
notes that for Althusius the key concept for politics in general was 'consociation' whereby a polity is a federally constructed edifice of layers of consociations. ${ }^{14}$ Consociations are the relationships and associations that are built through family and kinship ties, civil associations such as (for Althusius) guilds and estates, and private associations. The participants in this 'societal federation' are both social and territorial, and thus there is a functional as well as territorial representation in the political sphere. ${ }^{15}$ Alain de Benoist notes that Althusius conceived of society as holistic and organic, and was composed of groups, not individuals, and these groups could not develop fully without being autonomous. Althusius viewed society from below, gradually reaching the top. $^{16}$

The important point to be emphasized is that society, and the people within it, organize and identify through various associations and relationships. Various levels of society are aggregate wholes of these relationships. The family is the aggregate whole of relations and 'consociations' between next of kin. Some 'consociations' are natural, such as the family, the community, or maybe even a nation of peoples. Some 'consociations' are not. It is not clear at what point these 'consociations' are no longer natural ones. However, continual application and recognition of the principle of subsidiarity would ensure that whatever levels of society and government become established and institutionally recognized would, at the least, remain representative of the smaller units of society of which they are composed. I would suggest that the principle of subsidiarity be more than just political organization on the smallest level possible, but political organization that emphasizes and recognizes the 'consociations' of which the larger level of government is an aggregate whole - a composite. Super ordinate levels of political 
and social authority should remain dependent upon affirmation and recognition by the smaller 'sub' units of society - the constituent parts which are manifestations of the 'consociations' and relationships that develop within societies. These 'sub' units do not have to be as small as possible - they only have to have some clear connection with the 'consociations' and associations which comprise society.

This notion does have intuitive appeal. On the surface, respect and application of this principle would seem conducive to more localized control over politics and social life, and empowers citizens of nations to a greater extent than might otherwise be the case. There are some very clear advantages to political organization which is reflective of this principle. In the introduction it was suggested that there are widely divergent ways in which societies and peoples organize and identify themselves. Subsidiarity, through federalism, is one way of accommodating for these differences. Kimberly Hendrickson notes that issues of morality, ethics, and civic virtue are not dealt within the American Constitution, but are matters left to local control by the states. National control over issues like morality would have been impossible at the time the Constitution was drafted, as different citizens require different types of regulation. ${ }^{17}$ Thus there is a sort of practical use in applying this principle as well, in that some issues are simply better addressed at a more local level.

In addition, subsidiarity is conducive to ensuring that self-determination by local populations is preserved because rules and actions are being implemented at levels of government where individuals are more involved and can be effectively represented. ${ }^{18}$ Accountability by local governments is preserved - a local population's dissatisfaction with actions can be effectively directed at the level of local government directly 
responsible for those actions. ${ }^{19}$ Upholding the principle of subsidiarity also maintains and enforces local identities, and allows governments to be more responsive to local needs.

To what extent has this principle actually been reflected in the development of nations? Nation-states - entities which are ostensibly composite wholes of sub-national units - can reflect the characteristics of the smaller units of society. However, if the principle of subsidiarity does not remain at the forefront of 'statehood' (the existence and development of these national entities) then the legitimate connection of the state with the constituent parts can be lost. In the next section I consider some of the historical developments surrounding the nation-state. Subsequent to this, I undergo an examination of the development and ongoing progress of federalist ideas and the principle of subsidiarity in Europe, with particular emphasis on the development of the European Union. Throughout, the nation-state and the federal ideal are understood as a process of unifying and integrating smaller parts into a larger cohesive whole.

\section{The Nation-State and Subsidiarity in Recent History}

Thomas Hueglin notes that a dramatic transition in political organization occurred in Europe throughout the $16^{\text {th }}$ and $17^{\text {th }}$ century. He states that “...the old European order of plural rule, loose and overlapping federal administration, and corporatist social allegiance and identity was challenged by a new statist order of centralized territorial power and its corollary, individualized social relations. ${ }^{, 20}$ A new statist age began to emerge, which found expression in the works of Thomas Hobbes. Hueglin observes that it aimed at the forceful eradication of all factions with alternative visions of liberty in society, and accepted the majority principle as the institutionalized guarantor of 
hegemony in thought and action. ${ }^{21}$ In such a society there was no place for subsidiarity as a principle of differentiated levels of decision-making. This differentiation would only indicate that the consolidation of hegemonic control had failed. Alexander Murphy notes that the modern state system is the "latest incarnation" of a political-territorial order that has its roots in $17^{\text {th }}$ century Europe. ${ }^{22}$ This order developed through changing understanding of principles based on the idea that the final authority over most, if not all social, economic, and political matters should be vested with those in control of the territorial units of which the system was composed. ${ }^{23}$

These concepts have important implications. With the advent of an age which actively pursued consolidation of power, it is questionable whether or not the nationstates that exist today, or that ever existed, were legitimate 'consociations' or aggregations of smaller units uniting and integrating to address common needs. Requejo observes that the demos of democratic systems (the units of which these systems are to be comprised) have not been determined through any procedural rules of liberal democracies, but from historical progress through wars, conquest, annexations, and exterminations and marginalizations of whole peoples. ${ }^{24}$

The nation-state never manifested itself as an inclusive entity dependent upon, and reflective of, the sub-national parts which subsumed its existence. Most nation-states were created through expansionary domination and conquests. Only later did some adopt liberal democratic principles, and only in the past century have concepts such as selfdetermination of peoples, human rights, and rights to civic and public political participation come to the fore in discourse concerning the politics of the nation-state. The modern state system is not based on any timeless principle of sovereignty or self- 
determination of peoples, or consolidating political powers between like-minded communities, but on the production of a normative concept that links authority, territory, population, and recognition in a very distinct and particular way. ${ }^{25}$ The nation-state is, therefore, a single model of political existence that developed under specific historical circumstances.

Nevertheless, federal principles of respect and recognition for the autonomy of sub-national regions have existed historically to some extent. The old Swiss confederation of 1291 , although not strictly a federal state, was a very loose alliance which would today be called a confederation. ${ }^{26}$ Ronald Watts notes that the medieval period saw self-governing cities in what is now northern Italy and Germany link in loose confederations for trade and defense purposes. ${ }^{27}$ Thus, there is a federal tradition that goes back a very long way.

In the more contemporary context, the value of keeping civic virtues and morality localized after the war of independence in the United States was recognized by the 'founding fathers'. Kimberly Hendrickson observes that the delegates to the constitutional convention of 1787 wished to keep the federal government out of the messy business of civic virtue as much as possible. ${ }^{28}$ The United States is still considered the first authentic federal state. The Constitution of the United States leaves questions of day-to-day regulations almost entirely to the states, letting them gauge the relative need for peace or virtue among their populations. ${ }^{29}$

Notwithstanding this history, the nation-state, and the standard characteristics it holds, enjoys widespread recognition, acceptance, and universal applicability around the world today. To what extent do these historical antecedents of federal principles still 
exist and play out? The European example suggests that there is still an attempt to accommodate for regional autonomy and local control in efforts to integrate peoples and communities today. Perhaps the European experience can offer insight into how subsidiarity may be recognized today.

\section{Federalism and Subsidiarity in Europe}

As noted previously, the notion of federalism in Europe does go back some time, and is by no means an entirely new development. Johannes Althusius who lived in the $16^{\text {th }}$ century is credited by some as the first federal theorist. With respect to Europe, conceptions of integration in Europe reflect some of the principles of federalism and subsidiarity referred to earlier. Ludger Kuhnhardt offers a quote ${ }^{30}$ by Oswald NellBreuning, a European political theorist: "In a Europe of Europeans, no less than in any other comparable political structure the size of a continent, the centralization of tasks should take place only when and where they cannot be accomplished as well or better on a lower level. This is as true of regions, provinces, Lander, communities and cities as it is of traditional nation-states." 31 The European Economic Community was established with the Rome Treaties of 1957 which was viewed as a process of extending decision-making to accommodate demands for a free-trade zone. ${ }^{32}$

Although ideas to integrate Europe somehow did originate before the World Wars, it was not until after the Second World War that enough people and actors were receptive enough to the idea for its implementation to begin. After the Second World War opinion among both elites and public was receptive to the initiatives of incremental federalism that were to be introduced by John Monnet in the 1950s. ${ }^{33}$ John Pinder notes that initially Britain opposed union of Europe and integration into the European 
Economic Community (EEC). However, the French frustrated Britain's position on this matter by ending negotiations to create a West European free trade area. The British then switched from being anti-integrationist to 'pragmatists' who wanted to join the community “...because they thought that Britain would have a better chance of influencing world affairs as one of a group of sovereign states than as a single sovereign state on her own." ${ }^{, 34}$ Thus, there is the direct perception and identification of a need to integrate. The notion of integrating Europe was initially led by economic considerations and interests.

After the Rome Treaties of 1957 initiatives to further integrate Europe took on a federal tone. In 1970 the Swiss writer and philosopher Rougemont published an 'open letter' to Europeans calling for European political union. He proposed this could occur by following the Swiss experience with unification and federalism. ${ }^{35}$ In his letter, Rougemont quoted three articles of the Swiss federal constitution: "Article 1: The people of the twenty-two sovereign cantons of Switzerland, united by the present alliance form as a whole the Swiss Confederation. Article 3: The cantons are sovereign as far as their sovereignty is not limited by the federal constitution, and as such, they exercise all the rights which are not delegated to the federal power. Article 5: The Confederation guarantees to the cantons their territory, the sovereignty within the limits set by article 3 , their constitutions, the liberty and the rights of the people." ${ }^{36}$ A significant amount of autonomy is left at the canton level, and it is important to note that this Swiss confederation occurred partly as a response to civil war. Unification and integration are carried out only to the extent that is perceived as necessary, with ongoing recognition for the importance and relevance of the pre-existing orders of society and government in 
what is now Switzerland. It was proposed that this same gradual process be applied to European integration.

The nature of European integration is also very important to note. The EC Treaty and the Treaty on European Union are clearly treaties. Both treaties were created by topdown acts of government not "peoples" - they cannot be considered constitutions or as agreements delineating any sort of supra-nation. The Treaty Establishing the European Community (1957 - and amended by the Treaty of Amsterdam in 1997) it is stated that:

The Community shall adopt measures with the aim of progressively establishing the internal market... which shall comprise an area without internal frontiers in which the movement of goods, services, people and capital is ensured.

Furthermore:

Every person holding the nationality of a Member State shall be a citizen of the Union. Citizenship of the Union shall complement and not replace national citizenship. ${ }^{37}$

The creation of the European Union and its origins do not suggest any attempt at any point to impose an integrated community with jurisdiction and authority overriding that of the Member States - no function for the Union was established without a perceived need. Thus, at first the European Union represented only an economic community. Integration was carried out in a manner that preserved the autonomy and authority of the constituent units over issue areas that remained best addressed at the member state level.

In 1992, the Maastricht Treaty on European Union (TEU) further expanded EU jurisdiction. However, the subsidiarity principle was upheld as a central constitutional principle. Community institutions are instructed to "respect . . . the principle of subsidiarity" as they carry out their responsibilities. ${ }^{38}$ The TEU is full of other references to the subsidiarity principle. For example, the TEU states that in the new EU "decisions are taken as closely as possible to the citizens."39 The TEU defines subsidiarity by adding the following new paragraph to the EC Treaty: "In areas which do not fall within 
its exclusive competence, the Community shall take action, in accordance with the principle of subsidiarity, only if and in so far as the objectives of the proposed action cannot be sufficiently achieved by the Member States and can therefore, by reason of the scale or effects of the proposed action, be better achieved by the Community." ${ }^{, 40}$ Thus, to this day, subsidiarity remains a critical principle which forms the basis of European integration and the continual mobilization of politics in Europe.

Thomas Hueglin provides an insightful observation into both the historical and contemporary relevance of the principle of subsidiarity and federalism for Europe today. He notes that the subsidiarity principle now anchored in the Maastricht Treaty can be traced back to 16th century European political thought, and in particular to the 17th century political theory of Johannes Althusius. This suggests that subsidiarity has its roots in an early-modern Europe not yet dominated by a fully sovereign nation-state system, and that it is “...therefore uniquely appropriate for the organization of a postnation-state European union. It is, in other words, the timeless operational principle of a federally organized democratic European polity." ${ }^{41}$ This quote sets out the far-reaching relevance and importance of this principle in Europe both historically and today. That this principle has origins prior to the abstract and standard unit of social mobilization which we know today - the state - and that this principle is still evident in the organization of political society today, imply the timeless importance of this principle. With respect to the European Union, the individual member states, recognized as legitimate collectives of political societies, receive support for continued control and autonomy over issues which are best addressed at a state level. There is no attempt by the Community to appropriate what has been mobilized and organized at the State level. 
Ferran Requejo, in an earlier reference here, noted that most nations today were established through conquest, wars, and annexations. In this context, he notes further that: “...plurinational federations show the need to revise, for moral as well as functional reasons, some of the traditional 'statist' assumptions that the hegemonic cultural groups have imposed under some homogenizing notions of "democratic citizenship" and "popular democracy". ${ }^{42}$ This statement may have been offered within the context of plurinational federations only. Perhaps, however, revisitation to the sub-national groups and constituent units, and recognition of the historical authorities and political cultures at these levels could accommodate the different ways in which humans organize themselves politically and socially. Integration in the European Union is done with a view to continually recognize the legitimacy and authenticity of the smaller levels of political organization - the Member States. Thus, subsidiarity is not merely the delegation of political authority to the smallest possible level of society. This principle implies the affirmation of the legitimate 'consociations' and aggregate groupings which exist in society at any level.

\section{$\underline{\text { Conclusion }}$}

At the outset, and in the second section, I established the nation-state as an entity that emerged as a response to particular historical circumstances and exhibits a series of specific traits. These include territorial sovereignty and the consolidation of power at a central level of government over a territory and its population. This represents only one means of organizing and mobilizing society politically and socially, as history, and society today, suggests. On the surface, therefore, there appears to be an incongruity 
between a standard form of political organization - that receives universal assent - and the reality that there are a multitude of ways in which societies and cultures are composed.

Nonetheless, federalism, and its theoretical foundation - subsidiarity, offer a framework within which it is possible to accommodate for the varieties of associations found within societies. All societies are composed of associations and 'consociations' which form aggregate groupings. These constitute political and social groups. The proliferation of the state system, and the consolidation and centralization of political authority on which it is based, can remain legitimate manifestations of these aggregate societies so long as the smaller sub-national units of society - the legitimate 'consociations' - are continually empowered and recognized. In concluding, I quote Alain de Benoist's remarks:

The sovereignty of the state is not absolute. Existing only as a result of organic cooperation of provinces or federated regions, which preserve a large part of their autonomy, the state consecrates new state laws, which establish cooperation and unity among the federated parties according to the principle ruling on lower levels: the state is superior to every province individually, but not to the entity they constitute collectively. ${ }^{43}$

No state is legitimate or sovereign in its own right. The sovereignty, legitimacy, and authenticity of any nation-state, indeed, any aggregate whole, is always dependent on the degree to which the constituent parts are continually affirmed and represented. This can only be done through respect and recognition of the principle of subsidiarity - the ongoing affirmation of the smaller sets of associations and groups which comprise the essence of any aggregate whole. 


\section{$\underline{\text { Notes }}$}

1 Ronald L. Watts, Comparing Federal Systems ( $2^{\text {nd }}$. Ed.) (Montreal and Kingston: McGill-Queen's University Press, 1999) 6-7.

2 Ibid, 7.

3 Luis Maria Bandieri, "Carl Schmitt and Federalism.” Telos, 22 (2002): 48.

4 David Cameron, "The Structures of Intergovernmental Relations." International Social Science Journal 53:167 (2001): 121.

5 Gary W. Vause, "The Subsidiarity Principle in European Union law--American Federalism Compared." Case Western Reserve Journal of International Law 27:1 (1995): 63-65.

6 Ludger Kuhnhardt, “Federalism and Subsidiarity.” Telos 91 (1992): 78.

7 Ibid, 79.

8 Alain de Benoist, “The First Federalist: Johannes Althusius.” Telos 118 (2000): 33.

9 Ibid, 32.

10 Ibid, 33.

11 Ludger Kuhnhardt, "Federalism and Subsidiarity," 82.

12 Ferran Requejo, "Federalism and National Groups." International Social Science Journal 53:167 (2001): 43.

13 Ibid, 46.

14 Thomas O. Hueglin, "Federalism, Subsidiarity and the European Tradition: Some Clarifications." Telos 100 (1994): 43.

15 Ibid, 43.

16 Alain de Benoist, "The First Federalist: Johannes Althusius." 33.

17 Kimberly A. Hendrickson, "The Survival of Moral Federalism." The Public Interest 148 (2002): 100.

18 Gary W. Vause, "The Subsidiarity Principle in European Union Law--American Federalism Compared." 67.

19 Ibid, 67.

20 Thomas O. Hueglin, "Federalism, Subsidiarity and the European Tradition: Some Clarifications." 38.

21 Ibid, 39.

22 Alexander B. Murphy, “The Sovereign State as Political-Territorial Ideal.” eds. Thomas J. Beirsteker, and Cynthia Weber State Sovereignty as Social Construct (Cambridge: Cambridge University Press, 1996) 82.

23 Ibid, 82.

${ }^{24}$ Ferran Requejo, "Federalism and National Groups." 42.

25 Thomas J. Beirsteker and Cynthia Weber, "The Social Construction of statesovereignty," eds. Thomas J. Beirsteker and Cynthia Weber, State Sovereignty as Social Construct (Cambridge: Cambridge University Press, 1996) 1-2.

${ }^{26}$ Ludger Kuhnhardt, "Federalism and Subsidiarity." 79.

27 Ronald L. Watts, Comparing Federal Systems 2.

${ }^{28}$ Kimberly A. Hendrickson, “The Survival of Moral Federalism.” 100. 
9 Ibid, 100.

30 Ludger Kuhnhardt, "Federalism and Subsidiarity." 79.

31 Oswald von Nell-Breuning, "Baugesetze der Gesellschaft: Solidaritat und Subsidiaritat." (1986), Second Edition (Freiburg: Herder Verlag, 1990) 145.

${ }^{32}$ Ludger Kuhnhardt, "Federalism and Subsidiarity." 80.

33 John Pinder, "European Community and Nation-state: A Case for Neo-federalism?" International Affairs 62:1 (1985-86) 42.

34 Ibid, 46.

35 Jacques Coenen-Huther, "Towards 'one Europe': Can the Swiss model work?" Innovation: The European Journal of Social Sciences 4:2 (1991): 303.

36 Ibid, 35.

37 Ilan Margalit Maazal, "What is the European Union?" B.Y.U. Journal of Public Law 16 (2002): 243.

38 Gary W. Vause, "The Subsidiarity Principle in European Union law--American Federalism Compared." 66.

39 Ibid, 66.

40 Ibid, 67.

${ }^{41}$ Thomas O. Hueglin, "Federalism, Subsidiarity and the European Tradition: Some Clarifications." 40.

42 Ferran Requejo, "Federalism and National Groups." 45.

43 Alain de Benoist, "The First Federalist: Johannes Althusius." 36.

\section{Bibliography}

Luis Maria Bandieri, “Carl Schmitt and Federalism.” Telos 22 (2002): 48-59.

Thomas J. Beirsteker, and Cynthia Weber, "The Social Construction of Statesovereignty," eds. Thomas J. Beirsteker and Cynthia Weber, State Sovereignty as Social Construct (Cambridge: Cambridge University Press, 1996) 1-22.

Nick Butler, "Future Perfect Union.” Foreign Affairs (2003): 78-81.

Simon Bulmer and William E. Patterson, "Germany in the European Union: Gentle Giant or Emergent Leader?” International Affairs 72:1 9-32.

David Cameron, “The Structures of Intergovernmental Relations" International Social Science Journal 53:167 (2001): 121-129. 
John Cameron and Tidings Ndhlovu, “The Comparative Economics of EU 'Subsidiarity': Lessons from Development/Regional Economic Debates" International Journal of Urban and Regional Research 25:2 (2001): 327-345.

Jacques Coenen-Huther, “Towards 'One Europe': Can the Swiss Model Work?" Innovation: The European Journal of Social Sciences 4:2 (1991): 303-315.

Alain de Benoist, “The First Federalist: Johannes Althusius," Telos, 118, (Winter 2000): 25-60.

Kimberly A. Hendrickson, "The Survival of Moral Federalism.” The Public Interest 148 (2002): 96-111.

Thomas O. Hueglin, "Federalism, Subsidiarity and the European Tradition: Some Clarifications." Telos 100 (1994): 37-56.

Andy W. Knight, “Towards a Subsidiarity Model for Peacemaking and Preventive Diplomacy: Making Chapter VIII of the UN Charter Operational." Third World Quarterly 17:1 (1996): 31-52.

Ludger Kuhnhardt, "Federalism and Subsidiarity." Telos 91 (1992): 77-87.

Ilan Margalit Maazal, "What is the European Union?" B.Y.U. Journal of Public Law 16 (2002): 243-261.

Alexander B. Murphy, "The Sovereign State as Political-territorial Ideal" eds. Thomas J. Beirsteker and Cynthia Weber, State Sovereignty as Social Construct (Cambridge: Cambridge University Press, 1996) 81-120.

John Palmer, “The Future is Federal,” New Statesman \& Society 9:395 (1996): 16-19.

Paul Piccone and Gary Ulmen, "Federalism in the Age of Postmodernity: Rejoinder to Hueglin and diZerega." Telos, 102 (1995): 167-177.

John Pinder, "European Community and Nation-state: A Case for Neo-federalism?" International Affairs 62:1 (1985-86): 41-54.

Elizabeth Pond, “A New Constitution for the Old Continent?" The Washington Quarterly 24:4 (2001): 29-40.

Ferran Requejo, "Federalism and National Groups." International Social Science Journal 53:167 (2001): 41-50. 
Simeon Richard, "Adaptability and Change in Federations." International Social Science Journal 53:167 (2001): 145-154.

Joel P. Trachtman, "Reflections on the Nature of the State: Sovereignty, Power, and Responsibility." Canada-United States Law Journal, 20 (1994): 399-416.

W. Gary Vause, "The Subsidiarity Principle in European Union Law--American Federalism Compared." Case Western Reserve Journal of International Law, 27:1 (1995): 61-82.

Ronald L. Watts, Comparing Federal Systems, $2^{\text {nd }}$ Ed., (Montreal and Kingston: McGillQueen's University Press, 1999).

Eric Wibbels, "Federal Politics and Market Reform in the Developing World." Studies in Comparative International Development 36:2 (2001): 27-53. 